\title{
Imagism and Imagery in the Selected Poems of Major Imagist Poets
}

\author{
Bakhtiar Sabir Hama ${ }^{1}$ \\ ${ }^{1}$ English Department, College of Basic Education, University of Sulaimani, Kurdistan Region, Iraq \\ ${ }^{1}$ English Department, Cihan University Sulaimani, Kurdistan Region, Iraq
}

\begin{abstract}
This paper explores imagism and studies the intrinsic literary features of some poems to show how the authors combine all the elements such as style, sentence structure, figures of speech and poetic diction to paint concrete and abstract images in the mind of the readers. Imagism was an early $20^{\text {th }}$ century literary movement and a reaction against the Romantic and Victorian mainstreams. Imagism is known as an Anglo-American literary movement since it borrows from the English and American verse style of modern poetry. The leaders of the movement set some rules for writing imagist poems. The authors of the group believed that poets are like painters; what the painters can do with brush and dye, poets can do it with language i.e. painting pictures with words. The poems are descriptive; the poets capture the images they experience with one or more of the five senses. They believed that readers could see the realities from their eyes because the texts are like a painting. In this paper, six poems by six prominent leaders of the movement will be scrutinized according to the main principles of the formalistic approach which is the interpretation and analysis of the literary devices pertained to the concrete and abstract images drawn by the poets. The poems are: In a Station of the Metro by Ezra Pound, Autumn by T. E. Hulme, November by Amy Lowell, Oread by Hilda Doolittle (H.D.), and Bombardment by Richard Aldington.
\end{abstract}

KEY WORDS: Abstract Image, Concrete Images, Imagism, Imagist Poem, Modern Poetry.

\section{INTRODUCTION}

There Imagism was an avant-garde movement in poetry during the early twentieth century, especially between the years 1912 and 1917. Imagism has roots in symbolism and is influenced by the classical Japanese and Chinese poetry, especially haiku. Mikics describes haiku as "a classic Japanese verse form that has been popular and influential among English-language poets, notably the Imagists" (2007). One of the leaders of the movement Amy Lowell in her book "Tendencies in Modern American poetry" states that "the truth is that

Koya University Journal of Humanities and Social Sciences (KUJHSS).

Volume 3, Issue 1, 2020.

Received 12 February 2018; Accepted 02 Dec 2019,

Regular research paper: Published 23 June 2020

Corresponding author's e-mail: bakhtiar.hama@univsul.edu.iq Copyright (C2020 Bakhtiar S. Hama This is an open access article distributed under the Creative Commons Attribution License.
'Imagism,' 'Imagist,' refers more to the manner of presentation than to the thing presented. It is a kind of technique rather than a choice of subject" (1917). Not only Lowell, but other major figures of the trend focus on description rather than telling stories; the believe that the function of imagist poetry is to paint a picture through which they can convey their message and thus it is more important than the message itself. They rely on words to create pictures in the minds of readers and then they leave the interpretation and the comprehension of the texts for them. Imagists believed that there was no need to write long poems as few words will suffice to capture the intended image.

Though the name Ezra Pound is mentioned here and there as the founder of the movement, the poetess Amy Lowell believed that she deserved the title. According to Mikics (2007), after publishing his essay A Few Don'ts by an Imagiste in 1913, Pound quarreled two years later with Amy Lowell over leadership of the Imagists: a fight she won, whereupon Pound derisively named the movement 'Amygism'. The fight over leadership did not diminish the significance of the movement and although 
it was active as a movement only between 1912 and 1917, its emphasis on economy of language and concrete imagery, and its advocacy of free verse, had a lasting influence, and these features became the hallmarks of modern poetry. Korg states that "the historians of Imagism agree that Pound was the publicist, rather than the inventor, of Imagist doctrines, but they disagree about the identity of the true founder" (2003). Pound had great influences on the rise of modern poetry, and Tryphonopoulos and Adams rephrase T. S. Eliot's view as they say that "Eliot argued in his introduction to Literary Essays that Pound was the most important contemporary critic of his kind" (2005).

\section{THE RULES AND FEATURES OF IMAGIST POETRY}

Imagist poets should follow certain rules for composing imagist poetry to be distinguished from other styles of early 1920s. The poets should use as few words as possible; the words were mostly adjectives. Snodgrass describes imagism as "the tight, precise construction of verse that calls up multiple meanings and implications through sound, rhythm, word etymology, and free-form syntax" (2000). According to this definition, one can realize that imagists had to eschew detailed description and compose wellorganized grammatical sentences. Their main concern was to imply suitable words in the right place. Lowell (1917) discusses that all the imagists found themselves in accord upon some simple rules, which are summarized below:

1. To use the language of common speech, but to employ always the exact word, not the nearlyexact, nor the merely decorative word.

2. To create new rhythms as the expression of new moods and not to copy old rhythms, which merely echo old moods. Imagists believe that the individuality of a poet may often be better expressed in free-verse than in conventional forms. In poetry a new cadence means a new idea.

3. To allow absolute freedom in the choice of subject.

4. Imagists are not a school of painters, but they believe that poetry should render specific points and avoid vague generalities. This distinguishes them from the cosmic poets who give too much detail and evade from their main aims.

5. To produce poetry that is hard and clear, never blurred nor indefinite.

6. Concentration is of the very essence of poetry.

The tenets oblige poets to directly deal with what is being talked about, not try to use fancy words and phrases to talk about it and they should avoid using any words or phrases that do not enrich the presentation.
Accordingly, the authors are economic in words and the dictions used should stand for one part of the image. They regarded the old rhythm boring; therefore, they needed to create new rhythms so that readers would feel and see the difference of their poetry. Lowell herself agreed that these rules were not new; they were essentials of all great poetry, but they had been flouted or disregarded by the previous poetic movements and thus they needed to be revived because they were features of great literature in general, not only poetry (ibid).

\section{Ezra Pound's In a Station of the Metro}

The apparition of these faces in the crowd:

Petals on a wet, black bough. (Cited in Beasley, 2007)

Beasley states that "this poem records the precise instant when a thing outward and objective transforms itself, or darts into a thing inward and subjective" (2007). The statement shows that Pound is both objective (realistic) and subjective (romantic). Objective in the sense that he takes the picture of a metro station in Paris where there are many people (crowd). Anyone who has been in such a place can see this, but describing the faces of the passengers as 'petals' is a mere personal attitude. The poem is metaphorical as he utilizes two metaphors to describe the people at the station. First he regards the passengers as 'apparition' when he describes them as ghosts who come and go quickly; some faces will appear suddenly and some others become invisible in the same mode. Secondly, the word 'petals' is implied to describe the faces of the individuals as beautiful as the coloured segments of flowers.

Pound draws a picture of some individuals. Each petal represents the face of an individual; this is metaphoric since the petal and face are similar in shape. Petals vary in colour just like human beings; therefore, this can be a reference to the people who are living in France. There are Europeans, Africans, Caucasian whites, Asians and Middle Easterners who are living in France as immigration to this country started in the middle of the 19th century after the industrial revolution and particularly after the First World War when workers from the French colonies came to France. These individuals all together paint a beautiful tableau and Pound's message is openly a rejection of racism on the basis of colour. He devotes all the literary and linguistic devices to achieve his purpose. Brinkman argues "just as it draws emphasis to the syntactical construction of the poem, isolating these words, phrases and marks of punctuation foregrounds the visual (specifically typographical) and musical features of the poem what Pound would call phanopoeia and melopoeia" (2009).

Phanopoeia refers to the words which suggest visual images. In this poem, words such as apparition, crowd 
and petals refer to the individuals and create the visual image; the picture of the people who are seen in a metro station. Furthermore, melopoeia is prosody, the musical and rhythmic quality of the poem. The whole text is only one sentence; it is divided into two parts separated by a semicolon. In the first part, the word 'apparition', provides a kinetic image and it is related to the coming and going of the passengers while in the second part readers can hear their footsteps which are expressed through the use of alliteration in the words (black bough). The repetition of the voiced consonant /b/ goes well with its unvoiced counterpart / p / in the word 'petals'. These sounds; one voiced and the other voiceless, produce the beats of music. Though it is very short, Pound painted a wonder picture and Milne is very much affected by the poem and says "Ezra Pound's 'In a Station of the Metro' is perhaps the best-known Imagist poem" (2000). The style and the choice of words obviously show Pound's mastery over language use to draw pictures of realistic mode.

\section{T. E. HULME'S AUTUMN}

A touch of cold in the Autumn night-

I walked abroad,

And saw the ruddy moon lean over a hedge

Like a red-faced farmer.

I did not stop to speak, but nodded,

And roundabout were the wistful stars

With white faces like town children.

Hulme severely criticized the conventional subject matter and the subjectivity of the romantic poetry in general and Georgian poetry in particular. According to Persoon and Watson, Hulme propounded free verse, concrete language, and the primacy of the image (2009). His ideas, as well as his few poems, greatly influenced Ezra Pound, the imagist movement, and modern poetry. Autumn is one of Hulme's best short poems published in 1909 in which he evokes the mood of an autumn night through two sharp images: the moon is 'like a red-faced farmer', the stars have 'white faces like town children' (Beasley, 2007).

Like other imagists, Hulme depends on symbols and images to convey his messages. It seems that he distrusts language to be able to portray the picture and thus he avoids detailed descriptions of the autumn night. In seven lines and 45 words, he paints two images; one of a ruddy moon compared to a red-faced farmer and another one of the wistful stars compared to the faces of the town children. When you look at the first picture, you really feel the cold as there is sensation in it. The poem starts with a poetic line and the words are harmonious. The phrase 'touch of cold' clearly shows the change of weather; it is a transitional season between summer and winter, colder than summer and hotter than winter. The verb (walked) also suggests that the weather is cool and still nice for an evening walk.

Walking on foot is significant because it gives the poet a chance to enjoy the sunset view at dusk. Maybe the reddish colour of the sky at dusk drags the author out of the city since the ruddy moon is the first thing draws his attention and the same colour is reflected on the face of the farmer who walks back home after a long day's hard labor. The writer cannot stop because the twilight, the period after sunset and just before night, is short, but the word (nod) proves that he admires the scenery. The words in this part paint a picture of an autumn evening at dusk.

In the second image, you sense the differences between rural and urban life. Life in the countryside is more difficult than life in the big cities; therefore, the faces of the town children glow bright. The speaker builds a bridge between city and the countryside. He starts his journey from the city or town and ends in the outskirts where he sees the red face of the farmer and then comes back to the town (white faces like town children). He draws the pictures to share with readers his feelings and the tranquility he senses; he does not want to spoil the calmness of that night and thus he only nods to express his admiration. Hulme wants readers to see the autumn night from his perspective and enjoy the natural scenery. The focal point in both pictures is colour (red and white). The first (red) marks the end of the day and the latter (white) suggests the start of the night; beauty and admiration are detected in both pictures.

\section{Amy Lowell's November}

The vine leaves against the brick walls of my house,

Are rusty and broken.

Dead leaves gather under the pine-trees,

The brittle boughs of lilac-bushes

Sweep against the stars.

And I sit under a lamp

Trying to write down the emptiness of my heart.

Even the cat will not stay with me,

But prefers the rain

Under the meagre shelter of a cellar window.

Amy Lawrence Lowell was born on February 9, 1874, in Brookline. In description of imagist poetry, Lowell states, "Imagist verse is verse which is written in conformity with certain tenets voluntarily adopted by the poets as being those by which they consider the best poetry to be produced. They may be right or they may be wrong, but this is their belief" (1917). Accordingly, the imagist poets follow certain rules, as mentioned earlier, while composing poems in order to produce the best. There should be complete harmony or congruity among all the parts of the text to draw a nice tableau. Milne writes "Amy Lowell spells out some of the 
features of Imagism. These include openness to all subject matter, the use of everyday speech and the presentation of a concentrated image" (2000).

The aforementioned tenets are clearly reflected in November. Lowell describes this cold and dark month of the year and how she feels through some concrete images and a simple language. The setting is her house; she is sitting at her window looking out. The first picture she takes is of 'vine leaves' which are rusty, broken and dead. She borrows the colour 'rusty' from metals to describe the autumn leaves which are changed and rent asunder. After they fall and get hurt, the leaves crawl and assemble under the pine trees to be protected from the rough wind that sweeps the lilac-bushes against the stars. T. S. Hulme in 'Autumn', uses red colour to portray a beautiful tableau, but Lowell uses colour red (rust) to show a sorrowful scene; death of the leaves in autumn (November).

The stars and the lamp create another picture in the mind of the reader which is of a November night. The image has two sides: the first side is the description of some natural elements she sees at that moment (lilac, stars, cat, rain) and the second side is the description of her solitude; even the cat prefers the rain rather than staying in the room with her. The feeling is attached to the second picture to keep it harmonious with the cold wind and the darkness and again it is compatible with the first picture which shows the lifeless plants seen outside her house because only in a situation like this one feels isolated and depressed (the emptiness of my heart). The cat prefers that thin edge of the window (meagre), at least it gives the cat the sense that there is something in the world that cares about it, but it cannot build any intimacy with the owner (the speaker of the poem) because she is downhearted. Maybe it has something to do with her life because she never married and even she was a social outcast because of her masculine and ugly features and for being called lesbian. Snodgrass states "Lowell earned a reputation for violating conservative standards by flaunting her obesity, swearing, smoking cigars, and having a samesex lover, actress Ada Dwyer Russell, with whom Lowell remained all her life" (2000).

\section{H. D.'s (Hilda Doolittle) Oread}

Whirl up, sea -

Whirl your pointed pines,

Splash your great pines

On our rocks,

Hurl your green over us -

Cover us with your pools of fir. (Cited in Childs and Fowler, 2006)

According to Bloom (2002) H. D. (HILDA DOOLITTLE) was the cofounder of Imagism with Ezra Pound and Richard Aldington (an English poet) who met with each other in various London tea-shops and discussed poetry. Aldington, who was the husband of H.D. only for one year, in his memoir, Life for Life's Sake confesses that he and Ezra Pound admired her poetry and regarded her as an imagist (Korg, 2003). Myth has recurrent existence in Lowell's poetry and she overthrew traditional male domination of myth to voice the female perspective (Snodgrass, 2000). Her poem "Oread" which is an example of imagist poetry contains the common features of imagism especially its brevity and simplicity of language.

In this poem, H.D. invokes nature and mythology. Oread is the mythological mountain nymph and the speaker of the poem. The tool used to draw the picture is four commanding verbs (whirl, splash, hurl and cover). The poem is short and the image is clear; land covered with sea water, but not smoothly. The verbs connote violent actions and make the meaning of the poem ambiguous. Childs and Fowler argue "the poem projected by Imagism is a laconic complex in which 'painting or sculpture seems as if it were just coming over into speech'. As a model, Pound chose the 'Oread' by H. D." (2006). According to this explanation, H.D. is probably drawing a picture of Oread sitting on top of the mountain and orders the sea to dash masses or particles of water on the cliffs of its thrown (mountain).

The poem is only one sentence divided onto six poetic lines, and the focal point is ocean water near the shore. In the second and the third lines, H.D. used 'pine' to refer to the sea water because pine is always green and the colour of water near the shore is also seen as green. In the last two lines the author directly manipulates 'green' to refer to the water 'hurled your green' because green is abstract and cannot be hurled and sea only owns water to throw it, nothing else. The word 'fir', an evergreen tree, is also utilized to refer to its colour. The writer used repetition as a stylistic technique to talk about the motion of water and its colour near the shores. Both water and the colour green are symbols of life and renewal. The speaker addresses the sea and orders it to bring back peace and life to the barren world which is represented by the 'rock' in the text. This interpretation is logical because the poem was written in 1915 during the First World War and the world was in chaos. It seems that the poet does not trust human power to end the war and thus she believes that only a supernatural power 'Oread' can end the turmoil. The figurative creature orders the sea to throw its powerful waves at land and erase the traces of war.

\section{Richard Aldington's Bombardment}

Four days the earth was rent and torn

By bursting steel,

The houses fell about us;

Three nights we dared not sleep,

Sweating, and listening for the imminent crash 
Which meant our death.

The fourth night every man,

Nerve-tortured, racked to exhaustion,

Slept, muttering and twitching,

While the shells crashed overhead.

The fifth day there came a hush;

We left our holes

And looked above the wreckage of the earth

To where the white clouds moved in silent lines

Across the untroubled blue. (Aldington, 1919)

Richard Aldington (1892-1962) was born Edward Godfree Aldington in Portsmouth, England. He is best known as a key figure in the imagist movement although he is also recognized for his work as biographer, editor, translator, essayist, and fiction writer whose career spanned five decades (Persoon and Watson, 2009). He is regarded as one of the founders of Imagism along with Ezra Pound and H.D. Macgowan says "Aldington spoke of imagism as an outgrowth of Hellenism" (2004), since the ancient Greek poets also wrote short poems for special occasions. This view is supported by Beasley as she states that "H.D.'s and Aldington's verse reflects a close engagement with the poetry of ancient Greece" (2007).

Aldington's Bombardment, though longer than the other poems selected for this study, is an imagist poem for some reasons such as: the language is very simple, there is no detailed or unnecessary description of the scenes and the abstract images, he takes the picture of the scenes he came across as a soldier in the British Army during the First World War and finally he expresses the exact feelings that he had as a soldier in the middle of a severe war. Aldington describes a set of objects which have become the formula of the emotion the poet wants to express.

In Bombardment, Aldington clearly expresses his feelings which are based on true experiences. He manipulates some objects (earth, steel, house, shells), a situation (dared not sleep, sweating, listening, slept, muttering and twitching, hush; left our holes) and a series of events (Four days..., Three nights..., The fourth night..., The fifth day...). All these elements are used to draw the picture of the war and how the soldiers, including Aldington himself, felt when they found themselves in that critical situation. Shelling, falling of the house and the fear one faces during a battle are realistic pictures, and even he portrayed the abstract feeling 'fear' through some verbs (dared not, sweating, listening, muttering, twitching). This goes well with Hulme's and Pound's concept of verbal image which (Beasley, 2007) mediates between the real world of experience and the conscious world of appearances.

The author precisely followed the rules of imagist poetry. He collected all the events of five days and four nights to draw concrete pictures (earth torn, houses fell, shell crash, wreckage of the earth) and to create abstract images (dare not, death, hush, silent). He directly deals with the destructions and the horrible feelings brought during and after the war. The first and second stanzas are specified to describe the battle field during the bombardment and the final stanza describes the aftermath of the bombardment. Readers can hear the shelling, see the ruined house and touch the fear in the heart of the troops because everything in the poem is objectified, even the emotion, and they are all made into a picture taken by Aldington to record the moments he spent in war.

The style is free verse and the author does not need long descriptions to make readers understand how soldiers feel in a battlefield because the words are accurately selected to create clear pictures in our minds and even the length of the lines are compatible with the images. The first line is long since he talks about the damages made to earth everywhere (a wide space), but the second line is short because exploding a shell (bursting steel) does not take a long time; the third line is a little longer than the second line because falling of the houses come after the explosion and lasts longer. Line 2 in stanza 3 'We left our holes' is short as the action does not need much time (coming out of the holes), but lines 3 and 4 are long because the writer talks about the damages and the traces of the war.

\section{CONCLUSIONS}

Imagism as an Anglo-American poetry movement played a great role in accelerating the birth of modern poetry. The poets of the age tried to detach themselves from the style of poetry in the previous eras such as Victorian and Romantic poetry.

The application of Formalist criticism was successful in this study because it studies all the elements in the literary text and how they work together to make a piece of art. In this study, the researcher paid attention to the features such as style, sentence structure, imagery, symbols, figure of speech, tone, and genre to identify the pictures drawn by the poets. The authors avoided obscurity and unnecessary descriptions so that people can obviously see and comprehend the images, and this was achieved by the simplicity of the language and the familiarity of the subject matters.

In all the samples, the poets capture certain moments through the lens of their cameras. The pictures are taken so carefully and the accuracy is so high that readers feel as if they were watching a movie or they are live audience to the events. For instance, readers can clearly see the people at the metro station, the sunset of the autumn evening, the falling leaves of the pine trees, the Oread sitting on his chair solemnly orders the sea to water the earth and the ruined houses and the scared soldiers. 
Behind each concrete picture, there is also an abstract image drawn by the words. The authors do not describe the situations alone, but they also express their emotions and feelings because they believe that form and content complete each other. Without content, the form or the picture is empty or is like a blank space since the poets take the picture of the scenes that they admire or have effects on them; otherwise the poem cannot be produced in such a high manner. For example, Pound uses only fourteen words, but when you read it you find yourself at a metro station standing behind the yellow line observing the passengers coming and going.

The pictures have souls and they speak about the true feelings of a poet in a realistic situation. The style, sentence structures, figures of speech and etc. are organized so unerringly that readers cannot miss a single frame. For instance, in Hulme's Autumn, red and white colours are foregrounded; in Lowell's November the fall of the leaves is highlighted to represent author's cold house and her loneliness, and in Aldington's Bombardment some actions (sweating, listening, sleeping, muttering, twitching) are manipulated to portray the soldiers' feelings and emotions and nouns (crash, death, exhaustion, shells, wreckage, white cloud) are utilized to picture the outcomes of war. In this way, all the literary and linguistic features are congruous with each other to produce attractive images.

\section{REFERENCES}

Aldington, R., 1919. Images of War: a book of poems. London: Beaumont Press, Page (30)

Beasley, R., 2007. Theorists of Modernist Poetry: T.S. Eliot, T. E. Hulme, Ezra Pound. London and New York: Routledge, Page (39).

Brinkman, B., 2009. Making Modern 'Poetry': Format, Genre and the Invention of Imagism(e). Journal of Modern Literature, 32 (2), pp. 20-40.

Childs, P. and Fowler, R., 2006. The Routledge Dictionary of Literary Terms. London and New York: Routledge, Page (118).

Korg, J., 2003. 'Imagism', in: Roberts, N. (ed.) A Companion to Twentieth-Century Poetry. Malden, MA, USA: Blackwell Publishing Ltd, Page (129).

Lowell, A., 1917. Tendencies in Modern American Poetry. New York: The Macmillan Company, Pages $(236,240,244)$.

Macgowan, C., 2004. Twentieth-Century American Poetry. Malden, MA, USA: Blackwell Publishing, Page (176).

Mikics, D., 2007. A New Handbook of Literary Terms. New Haven and London: Yale University Press, Page (140).

Milne, I. M., 2000. Poetry for Students. Volume 9. New York: Gale Group, Page (257).

Persoon, J. and Watson, R. R., 2009. British Poetry, 1900 to the Present. New York: Facts On File, Inc., Pages $(6,235)$.

Snodgrass, M. E., 2000. American Poets of the 20th century. Lincoln, Nebraska: Cliffs Notes, Inc., Pages $(32,60)$.
Tryphonopoulos, D. P. and Adams, S. J., eds., 2005. The Ezra Pound Encyclopedia. London: Greenwood Press, Page (71).

https://www.poemhunter.com/poem/autumn-17/

https://www.poemhunter.com/poem/november-31/ 